\title{
The mode of action of anabolic agents: the effect of testosterone on muscle protein metabolism in the female rat
}

\author{
By J. A. MARTINEZ, P. J. BUTTERY* AND J. T. PEARSON \\ Department of Applied Biochemistry and Food Science, University of Nottingham School \\ of Agriculture, Sutton Bonington, Loughborough, Leics. LE12 5RD
}

(Received 14 February 1984 - Accepted 22 March 1984)

1. Testosterone ( $1 \mathrm{mg} / \mathrm{kg}$ body-weight per $\mathrm{d})$ given subcutaneously to female rats increased their growth rate and food conversion efficiency but not their food intake compared with that of the placebo-oil controls. A higher dose of testosterone ( $10 \mathrm{mg} / \mathrm{kg}$ body-weight per d) failed to increase the daily weight gain.

2. The increased growth rate of the testosterone-treated rats appeared to occur in the whole body and not specifically in muscle. There were no significant changes in body composition.

3. The fractional synthetic rate of gastrocnemius muscle protein was higher in the hormone-treated rats than in controls. This contrasts with previous results for the anabolic agent trenbolone acetate and reflects differences in the mode of action of these two different steroids, both with androgenic properties.

The rate of protein deposition is determined by the balance between the rates of protein synthesis and protein degradation in any particular tissue. This fine balance is influenced by a variety of factors, especially the diet, the breed and the sexual and hormonal status of the animal (Waterlow et al. 1978). At the cellular level, in particular for muscle, the hormonal balance of the animal is of prime importance and this can be exploited to increase growth and feed conversion efficiency of farm animals (Heitzman, 1980). A commercially viable method is the implantation of anabolic agents with hormonal activity, to increase the rate of protein deposition in cattle. The hormone-like substance trenbolone acetate (3-oxo-17-hydroxy-4,9,11-estratriene acetate) works well in female animals but with castrates an oestrogenic agent is also required. This compound increases the rate of muscle protein deposition in sheep by decreasing the rate of muscle protein catabolism and, to a lesser extent, the rate of muscle protein synthesis (Sinnett-Smith et al. 1983). Circumstantial evidence from 3-methylhistidine excretion values from cattle also supports this suggestion (Harris et al. 1984). These studies with farm species are in agreement with the much more detailed reports on the female rat (Vernon \& Buttery, 1976, 1978 a,b). The mode of action of trenbolone acetate is not well understood, but is often thought to be related to its androgenic properties.

Testosterone is anabolic in many species, but there appear to be few reports from whole-body experimentation which discuss its influence on muscle protein turnover in female animals, although some available evidence would indicate that muscle protein synthesis should be stimulated (de Loecker, 1965; Florini, 1970; Kochakian, 1975). In the present study we report the effect on female rats of exogenously applied testosterone in order to compare the results with those of our previous studies with the androgenic agent trenbolone acetate.

\section{MATERIALS AND METHODS}

\section{Animals}

Female rats (Wistar strain, specific pathogen free) given a standard laboratory diet (Ward \& Buttery, 1980) ad lib. were used in all the experiments. Water was always available and the animal house was kept at $22^{\circ}$ with a $12 \mathrm{~h}$ light $-12 \mathrm{~h}$ dark cycle. Animals were

* For reprints. 
acclimatized to the experimental cages for several days before the start of the experiments and were weighed at the same time each day. Testosterone propionate (Sigma Chemical Co., London) was dissolved in maize oil such that the required dose was present in $0.1 \mathrm{ml}$. Placebo injections of maize oil alone were given to the control animals. Injections were given daily, at $\mathbf{1 6 . 0 0}$ hours, subcutaneously via the neck skinfold.

In Expt 1, six rats were given $1 \mathrm{mg} / \mathrm{kg}$ body-weight (BW) per d, six rats $10 \mathrm{mg} / \mathrm{kg} \mathrm{BW}$ per $\mathrm{d}$ and six others acted as controls. The weights of liver, kidney and uterus were determined at the end of the experiment.

In Expt 2, the fractional synthetic rate of the gastrocnemius muscle protein was determined in female rats whose BW at the start of the experiment was approximately $100 \mathrm{~g}$. The six control rats were given a daily subcutaneous injection of maize oil $(1 \mathrm{ml} / \mathrm{kg} \mathrm{BW}$ per d) while the twelve treated animals were injected with maize oil with the addition of testosterone $(1 \mathrm{mg} / \mathrm{kg} \mathrm{BW}$ per d). Six of these treated animals were killed by cervical dislocation when they reached approximately $130 \mathrm{~g}(7 \mathrm{~d}$ of treatment). The remaining twelve animals were killed when the six controls reached $130 \mathrm{~g}(9 \mathrm{~d})$. Another group of six rats $(103.6(\mathrm{SE} 4.2) \mathrm{g}$ ) were killed in order to evaluate the weight and protein content of the gastrocnemius muscle of the experimental animals at the start of the trial.

Expt 3 was carried out to test the effect of testosterone on food intake and body composition in the entire female. Twelve rats (six per group) were allocated to individual metabolism cages in order to estimate the food intake. Any food spillage was also recorded. In this experiment, testosterone $(1 \mathrm{mg} / \mathrm{kg} \mathrm{BW}$ per d) was administered for $9 \mathrm{~d}$.

\section{Analytical procedures}

Fractional synthetic rates of mixed muscle protein were determined by the method of Garlick et al. (1980) by injecting a single flooding dose of $\mathrm{L}-\left[4-{ }^{3} \mathrm{H}\right]$ phenylalanine (Amersham International plc, Bucks) via a lateral tail vein $(1 \mathrm{ml} / \mathrm{kg} \mathrm{BW}$ : $150 \mathrm{~mm}$-phenylalanine, $50 \mu \mathrm{Ci} / \mathrm{ml}$ in water). After $10 \mathrm{~min}$ the animals were killed by cervical dislocation and the gastrocnemius muscle from the right leg was rapidly removed, frozen in liquid nitrogen and stored at $-40^{\circ}$ until analysed. Other tissues were carefully excised and weighed. Determination of the specific activity of $\left[{ }^{3} \mathrm{H}\right]$ phenylalanine involved its enzymic conversion, by means of tyrosine decarboxylase (EC 4.1.1.25) (Sigma Chemical Co.), to $\beta$ phenethylamine. The fluorimetric measurement of this derivative was performed according to the method of Suzuki \& Yagi (1976) except that a single extraction with heptane was used. The fractional synthetic rate $\left(K_{s}\right)$ of protein was calculated as follows:

$$
K_{s}=\frac{S_{b} \times 100}{S_{a} \times t},
$$

where $S_{b}$ and $S_{a}$ are the specific activities of protein-bound and tissue-free phenylalanine respectively and $t$ is the time of labelling (approximately $10 \mathrm{~min}$ ). The free specific activity declined by a small amount (less than $5 \%$ ) during this $10 \mathrm{~min}$ period, and was neglected as suggested by Garlick et al. (1983) and Preedy et al. (1983). The time component used in the calculation included the time taken to freeze the sample. The fractional degradative rate was estimated from the difference between the estimated net protein deposition from the start of the treatment period and the calculated protein synthesis (day 7 or day 9 as appropriate).

Body composition was determined in the animals after the alimentary tracts were emptied. The dead animals were placed in securely sealed polyethylene bags and frozen $\left(-20^{\circ}\right)$. The bodies were cut into small pieces, put in $0 \cdot 2 \mathrm{M}$-sulphuric acid and portions were freeze-dried. Total body water, fat, ash and crude protein $(\mathrm{N} \times 6.25)$ were determined according to the Association of Official Agricultural Chemists (1970). 
Table 1. Expt 1. The effect of testosterone at two different doses ( 1 and $10 \mathrm{mg} / \mathrm{kg}$ body-weight $(B W)$ per $d)$ on growth rate and organ weights of the entire female rat after $14 d$ of treatment

(The values were submitted to analysis of variance (adjusted by covariance when appropriate) for a complete randomized design with three treatments. The sums of squares were partitioned into control $v$. treatments ( $1 \mathrm{df}$ each). There were six animals in each group)

\begin{tabular}{|c|c|c|c|c|c|c|}
\hline \multirow{2}{*}{$\begin{array}{l}\text { Treatment... } \\
\text { Dose (mg/kg BW per } \mathrm{d}) \ldots\end{array}$} & \multirow{2}{*}{$\begin{array}{l}\text { Control } \\
- \text { (a) }\end{array}$} & \multicolumn{2}{|c|}{ Testosterone } & \multirow{2}{*}{$\begin{array}{l}\text { Pooled } \\
\text { SE of } \\
\text { difference }\end{array}$} & \multicolumn{2}{|c|}{$\begin{array}{l}\text { Statistical significance } \\
\text { of difference between } \\
\text { treatments }\end{array}$} \\
\hline & & 1 (b) & $10(c)$ & & $\mathrm{a} v . \mathrm{b}$ & a v. c \\
\hline Initial BW (g) & $88 \cdot 6$ & $88 \cdot 6$ & $89 \cdot 5$ & $2 \cdot 39$ & NS & NS \\
\hline Final BW (g) & $141 \cdot 6$ & $154 \cdot 1$ & $143 \cdot 3$ & 5.07 & $P<0.05$ & NS \\
\hline Daily wt gain (g) & $3 \cdot 5$ & $4 \cdot 5$ & 3.4 & 0.28 & $P<0.05$ & NS \\
\hline Liver* (g/kg BW) & 48 & 46 & 44 & $3 \cdot 4$ & NS & NS \\
\hline Kidney* (g/kg BW) & $9 \cdot 3$ & $9 \cdot 9$ & $11 \cdot 4$ & $0 \cdot 4$ & NS & $P<0.01$ \\
\hline Uterus* $(\mathrm{g} / \mathrm{kg} \mathrm{BW})$ & $1 \cdot 4$ & 0.9 & $0 \cdot 7$ & $0 \cdot 1$ & $P<0.001$ & $P<0.001$ \\
\hline
\end{tabular}

NS, not significant $(P>0.05)$.

* Tissue weights were determined as wet weights.

Table 2. Expt 2. The effect of testosterone $(1 \mathrm{mg} / \mathrm{kg}$ body-weight $(B W)$ per $d)$ on growth rate and organ weights of the entire female rat after 7 and $9 d$ of treatment

(The values were submitted to analysis of variance (adjusted by covariance when appropriate) for a complete randomized design with three treatments. The sums of squares were partitioned into control $v$. treatments ( $1 \mathrm{df}$ each) and between both treatments ( $1 \mathrm{df})$. There were six animals in each group)

\begin{tabular}{|c|c|c|c|c|c|c|}
\hline \multirow{2}{*}{$\begin{array}{l}\text { Treatment... } \\
\text { Duration }(\mathrm{d}) \ldots \\
\text { Dose }(\mathrm{mg} / \mathrm{kg} \mathrm{BW} \text { per } \mathrm{d}) \ldots\end{array}$} & \multirow{2}{*}{$\begin{array}{c}\text { Oil } \\
\text { placebo } \\
9 \\
-(a)\end{array}$} & \multicolumn{2}{|c|}{ Testosterone } & \multirow{2}{*}{$\begin{array}{l}\text { Pooled } \\
\text { SE of } \\
\text { difference }\end{array}$} & \multicolumn{2}{|c|}{$\begin{array}{c}\text { Statistical significance } \\
\text { of difference between } \\
\text { treatments }\end{array}$} \\
\hline & & $\begin{array}{c}7 \\
1(b)\end{array}$ & $\begin{array}{c}9 \\
1(c)\end{array}$ & & $\mathrm{a} v . \mathrm{b}$ and $\mathrm{c}$ & b v. c \\
\hline Initial BW (g) & $104 \cdot 3$ & $104 \cdot 3$ & $103 \cdot 4$ & 1.95 & NS & NS \\
\hline Final BW (g) & $130 \cdot 3$ & $129 \cdot 1$ & $135 \cdot 1$ & $2 \cdot 93$ & NS & $P<0.05$ \\
\hline Daily wt gain $(\mathrm{g} / \mathrm{d})$ & $2 \cdot 9$ & $3 \cdot 7$ & $3 \cdot 6$ & $0 \cdot 28$ & $P<0.01$ & NS \\
\hline 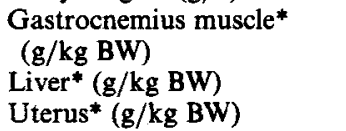 & $\begin{array}{r}5 \cdot 1 \\
48 \cdot 0 \\
1 \cdot 4\end{array}$ & $\begin{array}{r}5 \cdot 2 \\
47 \cdot 9 \\
0 \cdot 9\end{array}$ & $\begin{array}{r}5 \cdot 1 \\
48 \cdot 3 \\
0 \cdot 9\end{array}$ & $\begin{array}{l}0 \cdot 1 \\
1 \cdot 3 \\
0 \cdot 1\end{array}$ & $\begin{array}{l}\text { NS } \\
\text { NS } \\
P<0.001\end{array}$ & $\begin{array}{l}\text { NS } \\
\text { NS } \\
\text { NS }\end{array}$ \\
\hline
\end{tabular}

NS, not significant $(P>0.05)$.

* Tissue weights were determined as wet weights.

\section{Statistical analysis}

Results are expressed as mean values with their standard errors or mean values and the pooled standard error of the difference. The significance of differences between groups was determined by analysis of variance (Expts 1 and 2) or by the Student's $t$ test (Expt 3). Treatments were normally considered to be not significantly different at $P>0.05$.

\section{RESULTS}

Testosterone at a dose of $1 \mathrm{mg} / \mathrm{kg} \mathrm{BW}$ per d stimulated the growth rate of entire female rats (Tables 1-3). The differences in daily gain between individual experiments was attributed to differences in the experimental conditions, e.g. in Expt 3 (Table 3) the animals 
Table 3. Expt 3. The effect of testosterone ( $1 \mathrm{mg} / \mathrm{kg}$ body-weight $(B W)$ per d) on growth rate, food intake, food conversion efficiency $(F C E)$ and empty-body composition in the entire female rat after $9 d$ of treatment

(Mean values with their standard errors for six rats per group)

\begin{tabular}{|c|c|c|c|c|c|}
\hline \multirow[t]{2}{*}{ Treatment... } & \multicolumn{2}{|c|}{ Oil placebo } & \multicolumn{2}{|c|}{ Testosterone } & \multirow{2}{*}{$\begin{array}{c}\text { Statistical } \\
\text { significance of difference } \\
\text { (Student's } \pm \text { test) }\end{array}$} \\
\hline & Mean & $\mathrm{SE}$ & Mean & SE & \\
\hline Initial BW (g) & $100 \cdot 2$ & $2 \cdot 03$ & $101 \cdot 6$ & $2 \cdot 04$ & NS \\
\hline Final BW (g) & $117 \cdot 4$ & $1 \cdot 25$ & $123 \cdot 2$ & 1.98 & $P<0.05$ \\
\hline Daily wt gain (g/d) & 1.9 & $0 \cdot 10$ & $2 \cdot 6$ & $0 \cdot 16$ & $P<0.01$ \\
\hline Food intake (g) & $112 \cdot 4$ & 1.60 & $113 \cdot 6$ & $3 \cdot 46$ & NS \\
\hline \multicolumn{6}{|l|}{$\mathrm{FCE}$ ( $\mathrm{g}$ food intake $/ \mathrm{g}$} \\
\hline BW gain) & $6 \cdot 6$ & $0 \cdot 29$ & $5 \cdot 3$ & 0.42 & $P<0.05$ \\
\hline Water $(\mathrm{g} / \mathrm{kg})$ & $613 \cdot 5$ & $8 \cdot 10$ & $609 \cdot 4$ & $4 \cdot 51$ & NS \\
\hline Crude protein $(\mathrm{N} \times 6.25)(\mathrm{g} / \mathrm{kg})$ & $187 \cdot 8$ & $1 \cdot 77$ & 189.5 & $3 \cdot 73$ & NS \\
\hline Fat $(g / k g)$ & $123 \cdot 2$ & $6 \cdot 54$ & $117 \cdot 1$ & 0.91 & NS \\
\hline
\end{tabular}

NS, not significant $(P>0.05)$.

Table 4. Expt 2. Effect of testosterone ( $\mathrm{lmg} / \mathrm{kg}$ body-weight $(B W)$ per $d)$ on gastrocnemius muscle protein metabolism in the entire female rat after 7 and $9 d$ of treatment

(The values were submitted to analysis of variance for a complete randomized design with three treatments. The sums of squares were partitioned into control $v$. treatments $(1 \mathrm{df}$ each) and between treatments ( $1 \mathrm{df})$. There were six animals in each group)

\begin{tabular}{|c|c|c|c|c|c|c|}
\hline \multirow{2}{*}{$\begin{array}{l}\text { Treatment... } \\
\text { Duration (d)... } \\
\text { Dose (mg/kg BW per d)... }\end{array}$} & \multirow{2}{*}{$\begin{array}{l}\text { Control } \\
9 \\
-(a)\end{array}$} & \multicolumn{2}{|c|}{ Testosterone } & \multirow{2}{*}{$\begin{array}{l}\text { Pooled } \\
\text { SE of } \\
\text { difference }\end{array}$} & \multicolumn{2}{|c|}{$\begin{array}{l}\text { Statistical significance } \\
\text { of difference between } \\
\text { treatments }\end{array}$} \\
\hline & & $\begin{array}{c}7 \\
1(b)\end{array}$ & $\begin{array}{c}9 \\
1(\mathrm{c})\end{array}$ & & $\mathrm{a} v . \mathrm{b}$ and $\mathrm{c}$ & b v. c \\
\hline $\begin{array}{l}\text { Gastrocnemius muscle protein } \\
\text { (mg/g wet tissue) }\end{array}$ & $22 \cdot 9$ & $22 \cdot 4$ & $22 \cdot 7$ & 0.31 & NS & NS \\
\hline $\begin{array}{l}\text { Fractional rate of gain } \\
\text { in protein }(\% / d)\end{array}$ & $3 \cdot 5$ & $4 \cdot 4$ & $4 \cdot 1$ & 0.16 & $P<0.01$ & NS \\
\hline $\begin{array}{l}\text { Fractional synthetic rate of } \\
\text { protein }(\% / \mathrm{d}) \\
\text { Fractional degradative rate of } \\
\text { protein* }(\% / \mathrm{d})\end{array}$ & $12 \cdot 6$ & $16 \cdot 3$ & $15 \cdot 0$ & $1 \cdot 10$ & $P<0.01$ & NS \\
\hline
\end{tabular}

NS, not significant $(P>0.05)$.

* Calculated from the difference between the mean fractional growth rate $0-7 \mathrm{~d}$ or $0-9 \mathrm{~d}$ and the mean fractional synthetic rate of muscle determined on day 7 or day 9 as appropriate (for comments on technique, see p. 520).

were in metabolism cages and given a crumbled diet. The growth stimulation was in each case evident within a few days of treatment and maintained throughout the experimental period, and confirms our previous observations (Vernon \& Buttery, 1978a). The higher dose of testosterone propionate $(10 \mathrm{mg} / \mathrm{kg} \mathrm{BW}$ per d) failed to stimulate growth, although a renotropic effect was observed. Testosterone treatment $(1 \mathrm{mg} / \mathrm{kg} \mathrm{BW}$ per d) caused no significant increases in the weights of liver and kidney relative to $\mathrm{BW}$ (Tables 1 and 2 ). The relative size of the gastrocnemius muscle was not increased (Table 2) nor was the body $\mathrm{N}$ 
content (Table 3). Indeed, there were no significant changes in carcass composition, although a slight increase in protein content at the expense of fat content was observed, which again suggests that testosterone induced a stimulation in growth rate which was due to a general body enlargement. Food intake $(\mathrm{g} / \mathrm{d})$ was not influenced by testosterone treatment (Table 3), and in consequence food conversion efficiency was increased $(P<0.01)$. The $K_{\delta}$ of the gastrocnemius muscle protein was stimulated in animals of both the same age and the same BW as the controls. Fractional degradative rate calculated from $K_{s}$ at day 7 or at day 9 as appropriate and the increase in fractional gain in protein from the initial day to day 7 or day 9 of the experimental period was also increased. The ratio, $K_{s}$ : fractional degradative rate remained unchanged (Table 4).

\section{DISCUSSION}

Early investigations with different species showed a wide range of myotropic responses after administration of testosterone (Kochakian \& Beall, 1950; Kochakian, 1959, 1965, 1975) and that the additional factors such as age, dose, diet and hormonal status have a profound influence on the character and location of the anabolic effect (Kruskemper, 1968; Kochakian, 1975). The stimulation of growth of female rats treated with testosterone confirms our previous observations (Vernon \& Buttery, 1978a) and those that show this treatment to increase $\mathrm{N}$ retention in female rats (Kochakian \& Beall, 1950). More detailed information of the experimental conditions would be required to interpret the failure of Rodway \& Galbraith (1979) to observe an effect on BW following testosterone treatment.

The low dose of testosterone did not affect the proportions of liver, kidney and gastrocnemius muscle, again suggesting a parallel effect on most body constituents. A similar study reported uniform changes in weight and composition of twenty-one muscles proportional to the changes in BW (Kochakian et al. 1956). Uterus, unlike the other tissues, was reduced in relative size which is consistent with the anti-uterotropic activity of this hormone (Lobl \& Maenza, 1975) and contrasts with previous observations with trenbolone acetate where the uterine weight was increased (Vernon \& Buttery, 1976) or not affected (Vernon \& Buttery, 1978b).

Hormones can alter both the rate of growth and the composition of the body, hence BW gain can not always be equated with protein gain. Our results show only a slight decrease in fat content and a small increase in protein content after administration of $1 \mathrm{mg}$ testosterone $/ \mathrm{kg} \mathrm{BW}$ per $\mathrm{d}$ to female rats. These findings are consistent with a previous report by Hervey \& Hutchinson (1973), who found a significant internal redistribution involving an increase of lean tissue and a decrease of fat only at a dose higher than $1 \mathrm{mg} / \mathrm{d}$. In general, the present findings support the conclusion that the increased BW of androgen-treated female rats results from a general increase in the body as a whole (Vernon \& Buttery, 1978 a).

The well-established anabolic effect of testosterone and related compounds (Kruskemper, 1968; Kochakian, 1975) is presumably mediated by specific receptors present in skeletal muscle (Michel \& Baulieu, 1980; Snochowski et al. 1980) which have been characterized in both male and female rats (Dube, 1976). This anabolic response apparently reflects a simple hypertrophy of muscle fibres, as there are no major changes in structure (Venable, 1966) or composition of skeletal muscle (Kochakian, 1975).

The present findings on gastrocnemius muscle protein synthesis, which can be taken as indicative of the skeletal muscle as a whole (Waterlow et al. 1978), are in good agreement with previous reports using intact and castrated male rats, where an increased ${ }^{14} \mathrm{C}$-labelled amino acid incorporation into muscle protein following androgen administration was observed (de Loecker, 1965; Rogozkin, 1979).

Calculations of the fractional protein breakdown rate from $K_{s}$ and fractional growth rate 
gave indications that treatment increased the rate of muscle protein breakdown, although it must be acknowledged that this method is associated with relatively large errors. These observations are consistent with reported evidence for the androgenic agent Durabolin (Dumelow et al. 1981) and for methandrostolone (Rogozkin, 1979) but in direct contrast to those obtained after administration of trenbolone acetate, where both the synthetic and degradative rates are decreased (Vernon \& Buttery, 1976, 1978 $a, 1978 b$ ).

Between days 7 and 9 the muscle protein $K_{s}$ of the treated animals fell. In the comparable experiment with trenbolone acetate (Vernon \& Buttery, 1978b), albeit using the continuousinfusion technique to measure protein synthesis, the placebo-oil group showed a similar fall, but the trenbolone-acetate-treated rats had very similar values for muscle $K_{\delta}$ on day 7 and day 14 of treatment. A plot of the difference from the mean of individual gastrocnemius protein gain $\left(K_{g}\right) v$. the difference from the mean of the individual $K_{s}$ (values from Table 4) yielded for the control animals a positive linear relationship with a slope close to unity $\left(K_{g}=0.78 K_{s}+0.06 ; r 0.90 ; P<0.025\right)$ and this has been taken to indicate that $K_{\delta}$ is the major factor controlling deposition rate (Garlick et al. 1973). No such correlation was observed with the 9-d-treated animals $\left(K_{g}=0.37 K_{s}+0.02 ; r 0.25 ; P>0.20\right)$. The ratio, $K_{s}$ : fractional degradative rate was not apparently affected by the testosterone treatment.

In vitro studies with cultured muscle cells have indicated that testosterone has a direct effect on protein synthesis (Powers \& Florini, 1975), but not on protein degradation (Ballard \& Francis, 1983). Perhaps in vivo other agents mediate the effect of exogenously applied testosterone on protein degradation.

Care must therefore be exercised in assuming that all substances with androgenic activity have similar effects on muscle, a conclusion reinforced by the comments of Lobley et al. (1983) on the energetics of trenbolone-treated cattle compared with those of untreated intact males.

The financial support of the Agricultural and Food Research Council is gratefully acknowledged. J. A. M. is supported by a grant from the Ministerio de Educacion y Ciencia of Spain. J.T.P. was a Ministry of Agriculture, Fisheries and Food student.

\section{REFERENCES}

Association of Official Agricultural Chemists (1970). Official Methods of Analysis, 11th ed. Washington, DC: Association of Official Agricultural Chemists.

Ballard, R. J. \& Francis, G. L. (1983). Biochemical Journal 210, 243-249.

de Loecker, W. (1965). Archives Internationales Pharmacodynamie 153, 69-78.

Dube, J. Y., Lesage, R. \& Tremblay, R. R. (1976). Canadian Journal of Biochemistry and Physiology 64, 50-56. Dumelow, N. W., Pearson, J. T., Essex, C. P. \& Buttery, P. J. (1981). Proceedings of the Nutrition Society 41, 57A.

Florini, J. R. (1970). Biochemistry 9, 909-912.

Garlick, P. J., Fern, N. \& Preedy, V. R. (1983). Biochemical Journal 210, 669-675.

Garlick, P. J., McNurlan, M. A. \& Preedy, V. R. (1980). Biochemical Journal 192, 719-923.

Garlick, P. J., Millward, D. J. \& James, W. P. T. (1973). Biochemical Journal 136, 935-945.

Harris, C. I., Milne, G., McDiarmid, R. W. \& Brewer, A. C. (1984). Proceedings of the Nutrition Society 43, 5A.

Heitzman, R. J., (1980). In Protein Deposition in Animals, pp. 193-214 [P. J. Buttery and D. B. Lindsay, editors].

London: Butterworths.

Hervey, G. R. \& Hutchinson, J. (1973). Journal of Endocrinology 57, 24.

Kochakian, C. D. (1959). Laboratory Investigation 8, 538-555.

Kochakian, C. D. (1965). In Mechanism of Hormone Action, pp. 192-213 [P. Karslan, editor]. London: Academic Press.

Kochakian, C. D. (1975). Pharmacological and Therapeutical Bulletin 1, 149-177.

Kochakian, C. D. \& Beall, B. (1950). American Journal of Physiology 160, 62-65.

Kochakian, C. D., Tillotson, C. \& Endahl, G. (1956). Endocrinology 58, 231-236.

Kruskemper, H. L. (1968). Anabolic Steroids. London: Academic Press.

Lobl, R. T. \& Maenza, R. M. (1975). Biology of Reproduction 13, 225-268. 
Lobley, G. E., Walker, A., Connell, A. \& Galbraith, H. (1983). Animal Production 36, 111-116.

Michel, G. \& Baulieu, E. E. (1980). Endocrinology 107, 189-198.

Novak, A. (1957). American Journal of Physiology 191, 306-312.

Powers, M. L. \& Florini, J. R. (1975). Endocrinology 97, 1043-1050.

Preedy, V. R., McNurlan, M. A. \& Garlick, P. J. (1983). British Journal of Nutrition 79, 517-526.

Rodway, R. G. \& Galbraith, H. (1979). Hormonal and Metabolic Research, 11, 489-490.

Rogozkin, V. (1979). Medicine and Science in Sports 11, 160-163.

Sinnett-Smith, P. A., Dumelow, N. W. \& Buttery, P. J. (1983). British Journal of Nutrition 50, 225-234.

Snochowski, M., Dahlberg, E. \& Gustafsson, J. A. (1980). European Journal of Biochemistry 111, 603-606.

Suzuki, O. \& Yagi, K. (1976). Analytical Biochemistry 75, 201-210.

Venable, J. H. (1966). American Journal of Anatomy 119, 271-302.

Vernon, B. G. \& Buttery, P. J. (1976). British Journal of Nutrition 36, 575-579.

Vernon, B. G. \& Buttery, P. J. (1978 a). Animal Production 26, 1-9.

Vernon, B. G. \& Buttery, P. J. (1978b). British Journal of Nutrition 40, 563-571.

Ward, L. C. \& Buttery, P. J. (1980). British Journal of Nutrition 44, 381-390.

Waterlow, J. C., Garlick, P. J. \& Millward, D. J. (1978). Protein Turnover in Mammalian Tissues and in the Whole Body, pp. 626-696. Amsterdam: Elsevier-North Holland. 